\title{
Intra-SADC Foreign Direct Investment: A Gravity Approach to South Africa Outward Investment
}

\author{
Onelie Nkuna ${ }^{1}$ \\ ${ }^{1}$ Chancellor College, University of Malawi / Reserve Bank of Malawi, Malawi \\ Correspondence: Onelie Nkuna, Reserve Bank of Malawi, Lilongwe, Malawi. E-mail: \\ onelienkuna@yahoo.co.uk
}

Received: October 27, 2015

Accepted: November 19, $2015 \quad$ Online Published: December 25, 2015

doi:10.5539/ijef.v8n1p79

URL: http://dx.doi.org/10.5539/ijef.v8n1p79

\begin{abstract}
This paper looks at intra-SADC FDI, focusing at South Africa outward FDI into SADC countries. LSDV and GMM estimation techniques are applied in a gravity model for the period 1999 to 2010. The study finds strong evidence that intra-trade and intra-FDI are negatively related, suggestive of a substitutive relationship between intra-SADC trade and intra-SADC FDI. The study also reveals that capital account openness, bilateral investment treaties, and labour availability are key in promoting intra-SADC FDI flows. Further, the study finds evidence that agglomeration effects are important for South African investors into SADC despite the fact that they are operating in a common region. The study also finds that FDI from developed countries complement with FDI from South Africa.
\end{abstract}

Keywords: SADC, foreign direct investment, trade, panel data, gravity model

\section{Introduction}

Foreign Direct Investment (FDI) from developing countries has risen sharply over the past two decades and much of it was directed to other developing countries, giving rise to the term "South-South FDI" (UNCTAD WIR, 2011). This, however, contradicts the neoclassical researchers regarding international capital flows which are meant to close the savings gap in developing countries (Page \& Willem, 2004). In other words, capital should flow from countries with relatively high capital-to-labor ratios to countries that have relatively low ratios. This was also suggested by developments in the Heckscher-Ohlin approach to trade by Mundell (1957). However, Lucas (1990) in his seminal paper pointed out a lot of factors that could explain why capital flow did not follow the predictions of the neoclassical theory. Later, Dunning (1993) also partly explained the developing countries' outward FDI through the Eclectic paradigm. In this model, he tried to explain FDI flows based on the Ownership-Location-Internalization (OLI) framework. Thus he combined key elements of three theories, namely; the neo-classical theory, the industrial organization theory and internalization theory, to come up with the so called eclectic paradigm.

Regionally, the creation of the Southern African Development Community (SADC) was intended to act as a catalyst for increased regional integration among which included facilitation of trade and investment flows to and within the region. Theoretically, traditional gains from a regional integration arrangement include; trade gains, increased return and competition and increased investment flows (Chipeta, 2010). In this regard, a lot of efforts have been made to advance the agenda of the SADC regional integration, including the signing of the SADC Trade Protocol in 1996 and Protocol on Investment and Finance in 2006. Despite these efforts at the regional level, the extent of intra-regional FDI activities is quite limited. Notwithstanding this, South Africa has emerged to be one of the most important source of FDI in Africa, particularly within the SADC region. FDI from South Africa was about USD 72.29 billion in 2010, out of which USD 15.23 billion was channeled to Africa (UNCTAD, WIR 2012).

Empirical work on intra-SADC FDI is very scanty and mostly descriptive in nature, for instance work by Page and Willem (2004) and AFDB (2013). This is largely due to scarcity of data. As such, the main objective of this paper is to empirically investigate what motivates intra-SADC FDI, focusing at South Africa outward FDI into the SADC region for the period 1999 to 2010 . The paper also revisits the question as to whether trade and FDI from South Africa to SADC countries complement or substitute each other. Further, the paper also investigate whether FDI from South Africa and that from the developed countries are complementary or compete with each 
other. The rest of the paper is organised as follows; section 2 reviews the theoretical and empirical literature while section 3 describes methodology. Section 4 presents empirical results and conclusions are drawn in section 5 .

\section{Literature Review}

Literature has a wide range of theories that try to explain the flow of FDI in general. However, Mundell's (1957) contribution to literature of FDI was significant as he was the first to introduce capital mobility assumption in the Hecksher-Ohlin framework. Vernon (1966), noting the weaknesses of the Neo-classical theory and in an attempt to explain FDI, developed a theory known as the product life cycle theory. Hymer (1976) also identifying several critical weaknesses of the Neo-classical explanation of FDI developed a theory which was linked to the market imperfection hypothesis. Though, later, there were so many approaches and theories, it is the Dunning's (1980) Eclectic Paradigm of the multinational enterprise which gained prominence in literature. According to the Dunning's eclectic paradigm, a firms decision to engage in FDI is influenced by three factors perceived by the enterprise which are; Ownership, Location and Internalization of specific advantages. The Eclectic model thus combines key elements of the neo-classical theory (location advantage); industrial organization theory (monopolistic or ownership advantage); and internalization theory (transactional efficiency). The ownership advantages are mainly firm's monopoly over its specific advantages mostly intangible assets including patents, trademarks, ownership of limited natural resources, and economies of scale and scope. Locational advantages include social advantages like distance, cultural similarities; political advantages; cost of transportation, telecommunication and market size. Internalisation occurs when a firm would want to protect against or exploit market failure. However, the Eclectic Paradigm has limited power to explain or predict particular kinds of international production and, even less, the behaviour of individual enterprises (Dunning, 1988). Notwithstanding this, many researchers have used the Eclectic Paradigm to understand firm's international investments.

With regard to the relationship between trade and FDI, Mundell (1957) demonstrated that international capital flows and trade are substitutes. Similarly, other theorists like Brainard (1993a) also argue that higher trade barriers and transportation costs lead to horizontal cross-border production expansion and thus stimulate international investment. As such, tariff barriers could motivate import substituting FDI or the so called "tariffjumping" argument. However, later other theoretical work has also demonstrated that trade and FDI can be complements for example Svensson (1984), Markusen (1984).

Whilst empirical literature for FDI is vast in developed countries, it is quite limited within the SADC region. A survey by UNIDO (2003) analyzed, among others, investor perceptions of ten African countries that included the following SADC countries; Mozambique, Madagascar and Tanzania. Their results confirmed Dunning's postulations that concluded that there are three distinct groups of investors; market seeking, resource seeking and export oriented production investors. Further, they found that political and economic stability, good business climate conditions, quality of infrastructure, legal framework, transparency of the investment climate and market conditions are among the important factors influencing investors to locate investment in Africa. Page and Willem (2004) also, following the works of Dunning (1980) analyses a number of factors in trying to understand FDI flows within Africa. Using qualitative analysis they found that the complementarity of trade and FDI was not supported by data. They also found that; relative market size was the main reason why small countries like Mauritius and Seychelles were investing outside their countries; bilateral investment treaties with South Africa seem not to be important; privatization in infrastructure significantly influenced investments; and changes in relative costs of production, in particular unit labour costs were the main reason Mauritius invested in Madagascar and Mozambique.

Bezuidenhout and Naudé (2008) applying the gravity framework but using total FDI into SADC and not directional FDI found that total FDI inflows are positively related with exports and that political instability and distance negatively affected FDI inflow. Unlike Bezuidenhout et al. (2008), Mhlanga et al. (2009) analyzed the determinants and trends of FDI flows to SADC, using project-level dataset for 14 SADC countries, for the period of 1994-2005. They found market size to have a positive impact on FDI flows. Other factors such as infrastructure development and openness of the economy to trade had a positive effect on FDI projects, although their significance was less robust. Their results are in contrast to Bezuidenhout et al. (2008) who found these factors to matter most. They also found that colonial ties and proximity of the investing country appeared to matter whilst macroeconomic variables appeared to be poor at explaining project-level FDI in the region. Lederman et al. (2010) compared SADC with two groups of developing countries with higher FDI per capita and also used the gravity framework. Unlike Mhlanga et al. (2009), they found the following factors to explain SADC's lower FDI inflows; economic fundamentals, previous growth rates, income, openness to trade, phone 
density, and adult share of the population. Interestingly, income and infrastructure did not matter as much in $\mathrm{SADC}$ as in the rest of the world.

A study by AFDB (2013) focused on a few SADC countries (Mozambique, Botswana, Mauritius, South Africa and Zambia) due to scarcity of data to analyse intra-SADC cross-border investment. Their approach was similar to Page and Willem (2004) in that it was qualitative in nature but different as they analysed both FDI and portfolio investments. The study categorised factors influencing intra-SADC FDI into enablers and barriers. The following were found to be enablers; proximity, market size, SADC protocol on finance and investment, special economic zones and regional stock markets. Whilst the following were found to be barriers to FDI; underdeveloped financial markets, institutional barriers and the quantum paradigm and business climate barriers.

\section{Methodology and Data}

Following other researchers reviewed in the preceding section like Lederman et al. (2010), the Dunning's eclectic theory provides our theoretical basis. This is applied in a gravity framework, in order to empirically analyse factors that influence South Africa outward FDI to SADC countries. The simple gravity model can be written as;

$$
Y_{i j t}=A_{z} \frac{X_{i t} X_{j t}}{\operatorname{Dist}_{\mathrm{ijt}}}
$$

This could be transformed in a logarithmic form as;

$$
\log Y_{i j t}=a_{0}+a_{1} \log X_{j t}+a_{2} \log X_{i t}+a_{3} D I S T_{i j}+\varepsilon_{\mathrm{ijt}}
$$

where; Yijt is the flow in FDI from home country $\mathrm{i}$ to host country $\mathrm{j}$ in period $\mathrm{t}$; $\mathrm{Xi}$ and $\mathrm{Xj}$ are the respective GDP of $i$ and $j$; Distij is the geographic distance between home country $i$ to host country $j$ and $\alpha_{1}, \alpha_{2}$ and $\alpha_{3}$ are constants. We augment the basic gravity model outlined above with other relevant variables as follows;

$$
\operatorname{LogFDI}_{i j t}=a_{0}+a_{1} \log G D P_{j t}+a_{2} \log G D P_{i t}+a_{3} D I S T_{i j}+a_{4} \mathrm{X}+\varepsilon_{\mathrm{ijt}}
$$

where $\log F D I_{i j t}$ is $\log$ of FDI stock from source country $i$ to host country j. Whilst the objective of our study is to understand intra-SADC FDI, we only focus on South Africa as a source country (i), being the major source of FDI in SADC. The potential sample for destination countries (j), however, includes all SADC countries. We use FDI stocks data due to its availability and data is obtained from South Africa Reserve Bank (SARB) and augmented with data from other countries and UNCTAD.

With regard to other variables, $\log G D P_{i t}$ is $\log$ of GDP of source countries; $\log G D P_{j t}$ is $\log$ of GDP of destination countries; $D I S T_{i j}$ is the geographical distance between the two countries thus South Africa and a recipient country, $\alpha_{0}$ is constant, $\alpha_{1} \alpha_{4}$ are regression coefficients, $\varepsilon_{i j t}$ are error terms. $X$ represents other factors relevant in explaining South Africa outward FDI flows. Below is an explanation of the relevance of the variables that we include in the model and their expected signs.

Trade (TRD): As stated earlier, early theorists like Mundell (1957) regarded trade and FDI as substitutes, while later, other researchers like Blomstrom and Kokko (1997) and Bezuidenhout and Naudé (2008) found a positive relationship between exports and FDI. On the other hand, Mitze et al. (2007), found that imports and outward FDI complement each other and there was a substitutive relationship between outward FDI and exports. Page (2004, p. 43) argues that investment in most of the African countries is for local sales particularly in services and distribution or for export to third countries, and not necessarily to replace the home countries' exports or to encourage trade back to it. In view of the foregoing, it is therefore important to investigate this relationship in the context of South Africa outward investment. The expected sign of the coefficient is, therefore, ambiguous. Trade data for South Africa to other SADC countries is used and obtained from IMF'S Direction of Trade and Statistics.

Market size (GDP): GDP size and GDP per capita are considered to give an indication of a country's market size as they reflect both high purchasing power of consumers and high real wages. SADC integration acted as an incentive for the firms in the region to exploit the enlarged market. It is therefore important to investigate the importance of SADC countries' market in attracting South Africa's outward FDI. The nominal GDP of the host countries is used as a proxy for market size. The expected sign of the coefficient is positive and data is obtained from Penn World tables.

Bilateral Investment Treaties (BIT): Bilateral investment treaties increase foreign entrepreneurs' confidence with regard to commitment by host countries to protect their investment and also provide an alternative dispute resolution mechanism other than the host state's courts. In this regard, they are said to attract investment inflows, 
as such the expected sign of the coefficient is positive. However, UNCTAD (1998) and Hallward-Driemeier (2003) found little evidence that BITs stimulated additional investment. South Africa has signed and enforced a number of bilateral investment treaties with either SADC or other countries. However, it is unclear as to whether these BITs have indeed promoted investment into these SADC countries, as such we include this variable in our model. A dummy variable for countries that have signed BITs with South Africa is used taking a value of one otherwise zero.

Institutional factors: Common wisdom would suggest that free cross-border capital flows are a reflection of good practice in government policy and corporate governance and that investors would pull out if companies and or countries were not well run (Ha-Joon Chang, 2007). However, the controversial flow of South-to-South investments to Sudan or the USD400 million investment in Anglo-platinum in Zimbabwe, at the time when the economic and political crises were at the peak in Zimbabwe may hint at different prevailing dynamics (Zampini, 2008). This therefore implies that the expected sign, a priori, is ambiguous, hence the importance of empirically examining it with regard to South Africa outward FDI into SADC. Rule of law (ROL) and Corruption Rank Indices (CPR) from World Bank ICRG database are used to capture the institutional environment. The higher the index the more stable/cleaner the country.

Capital Account Liberalization (KA): It is generally argued that the regulatory framework both of the source and host countries has a significant impact on FDI. However, Aseidu (2006) found that controls on capital account have insignificant influence on FDI in Sub Saharan Africa different from Middle-East and North Africa. Against this background, and the fact that many SADC member states though open to foreign investment in several sectors still have limits on foreign investment in certain strategic sectors, it is important to empirically ascertain the significance of this variable in our study. Data is obtained from Chin and Ito (2013). The index is based on the binary dummy variable that codify the tabulation of restrictions on cross-border financial transactions reported in the IMF's Annual Report on Exchange Arrangements and Exchange Restrictions (AREAER). The higher the index the more open the capital account, hence a positive sign is expected.

Natural Resource Availability (NRA): The region's rich natural resources continue to be a critical factor in attracting FDI from other regions, as such FDI is expected to be positively related with natural resources. On the other hand, natural resources generate macroeconomic uncertainty and thereby crowds out FDI consistent with the literature on the "curse of natural resources" (Sachs \& Warner, 1995). The expected sign, therefore, is ambiguous hence important to study for South Africa outward FDI into SADC. Some studies use oil export revenues as a proxy for availability of natural resources, however, this measure would be irrelevant in our study, as apart from Angola no other SADC member state produces oil. We therefore use natural resource rent over GDP as a measure of natural resource availability and data is obtained from World Bank Development Indicators.

Infrastructure development (TEL): Infrastructure development is said to be a magnet of FDI as it reduces the cost of doing business. In this case, therefore, the expected sign is positive. However, others like ODI (1997) have argued that poor infrastructure has the potential for attracting significant FDI if host governments permit more substantial foreign participation in the infrastructure sector. Furthermore, others have argued that most FDI flows to Africa are mostly in natural resources, as such, it does not matter whether infrastructure is developed or not. SADC is facing a lot of infrastructural challenges. Notwithstanding this, the region has made significant progress in regional infrastructure development (for instance in energy, transportation and information technology and communications systems projects), particularly with the adoption of the Regional Infrastructure Development Master Plan (RIDMP) in 2012. In this regard it is important to empirically examine the significance of this variable. A proper measure of infrastructure development would be logistics performance index or infrastructure index (Note 1). However, due to unavailability of data this study just uses phone density (sum of subscription of mobile and fixed lines per 100) as a proxy. Data is obtained from World Bank Development indicators.

Distance (DIST) or common border (CB): Distance increases the cost of doing business and would therefore deter FDI. While geographical distance is a natural factor, there is a role government can play to reduce the transactional and informational barriers between countries (see Loungani, 2002 et al.). Arguably, if distance is a hindrance to trade then it would induce FDI to serve those distant markets. We use common border dummy taking 1 if have a common border otherwise zero.

Macroeconomic Indicators: Unstable macroeconomic environment deter FDI. Though there has been some gains on the macroeconomic front with inflation and external debt remaining rather stable in the SADC region, on the other hand, other indicators like budget deficits and current account balances which continue to be in 
persistent deficits, remain worrisome. In view of this, it is important to investigate this factor with regard to South Africa outward investment to the region. In this study, we use Exchange rate volatility (EV) and inflation volatility (IV) both measured by the standard deviation of exchange rate and inflation, respectively. We use both variables since in some countries the exchange pass-through effect is not that large. A negative sign is expected and data is obtained from the IMF's IFS.

Availability of labor force (POP): Cheap and readily available labour force is a significant attraction to foreign investors as this directly reduces the cost of production. Availability of cheap labour force is said to have been one one of the drivers of South African investments in SADC, hence it is important to empirically investigate this. Considering that a significant proportion of FDI from South Africa are in the service sector, the best measure would have been secondary school enrolment. However, due to unavailability of this data for the host countries under study, we use population of age group 15-64 as share of total population.

We further take into consideration two important extensions: first, we explicitly take into consideration the role played by the agglomeration effect. The model to be estimated, therefore, is as follows;

$$
\operatorname{LogFDI}_{i j t}=a_{0}+a_{1} \operatorname{LogGDP}_{j t}+a_{2} \operatorname{LogGDP}_{i t}+a_{3} D I S T_{i j t}+a_{4} X+a_{5} \log F D I_{i j t(-1)}+\varepsilon_{\mathrm{ijt}}
$$

where $\operatorname{LogFDIijt}_{(-1)}$ is the lagged dependent variable to capture the agglomeration effect. Numerous studies have shown that agglomeration effect has a positive impact on FDI. It is argued that country-specific knowledge tends to be passed from firm to firm, and some firms often pursue a follow-my-leader strategy (Meyer \& Skak, 2002). In general, the existing FDI stock signals foreign direct investors the extent of a country's experience with foreign investors and hence guides new investors in choosing a location of investment. We therefore test if this is valid to the case of South Africa outward FDI. We use the lagged value of the dependent variable following Campos and Kinoshita (2003), who found it to have a positive and significant impact on current FDI.

Secondly, we extend the model by testing whether FDI from developed economies (the north) compete or complement with FDI from South Africa. We do this by including FDI from OECD countries as an additional variable. The equation is estimated as follows;

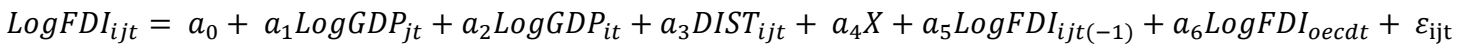

where LogFDIoecdt is FDI from OECD countries, and following Ma and Assche (2011), we use FDI from OECD to proxy FDI from the developed countries. Data is obtained from OECD database.

\section{Empirical Results}

Preliminary analysis of data is conducted and summary statistics (Appendix A) indicate that there is high variability in almost all variables. $T$ is fairly short $(T=12)$, as such there are no potential problems of panel unit root. Causality tests are done to check if this could be a source of endogeneity problem. Panel causality tests (Appendix B) show that there is reverse causality from LogFDI stock to LogROL and CB. In view of this, GMM estimation techniques are also employed apart form OLS with fixed effects, so as to obtain robust results. Since LogGDPjt is used to scale down the variables and is highly correlated with other variables like LogTRD, it is dropped from the model (Appendix C). There are data gaps in our series which would potentially lead to problems of selection bias and skewness of data. This problem can be solved by either adding 1 then applying the logarithmic transformation so that when we take their logs they would be zero (Eichengreen \& Irwin, 1995). Hence we use the logarithmic transformation to counter this problem.

To determine which panel method of estimation to use, various tests are done and results are shown in Appendix D. The pooled model is rejected in favour of both the random and fixed effects models. The fixed effect model is then tested against the random effects model using the Hausman test. The fitted model, however, fails to meet the asymptotic assumptions of the Hausman test. In view of this, the study just employs the fixed effect model as we do not assume that the individual heterogeneity is random. The study includes the cross-section effects as they are found to be jointly significant. The Sargan test of over identification indicates that in some cases the instruments are valid while in other cases they are weak. This is not surprising as our sample is fairly small and GMM tends to reject true hypotheses in small samples (Gujarati, 2003). The study, however, reports results for both OLS and GMM to raise confidence in our results.

\subsection{South Africa Outward FDI}

To establish the relationship between FDI and trade, firstly, the FDI regression is estimated and results in Table 1 (model 1) indicate a negative and significant relationship between FDI flow and trade. Using exports and imports as separate variables (model 2), the coefficient for both imports and exports are negative and significantly related with FDI. The study further estimates reverse regressions where trade is a dependent variable and FDI is one of 
the regressors. Results (Appendix E) further reveal a negative relationship between trade and FDI. The results are similar to Mitze et al. (2007) and also in support with qualitative findings by Page and Willem (2004). The estimated results are, however, in contrast to Bezuidenhout and Naudé (2008) for SADC. The findings are contrary to expectations, as the creation of SADC was, among others, intended to promote trade within the region which was expected to have a complementary effect on investment. This therefore implies that trade policies would not positively influence FDI. As such, member countries ought to pursue explicit FDI policies to attract FDI. The negative relationship could partly be due to the fact that the pace of implementation of a fully liberalized free trade regime and hence integration is rather slow, hindering the region to reap the potential dynamic gains from integration. Further the results could also be due to the nature of the sectors in which South African investors have largely invested. In view of this, a sector specific analysis of the relationship is required.

Table 1 . The gravity model of South Africa outward FDI

\begin{tabular}{|c|c|c|c|c|}
\hline Dependent variable LFDI & $\begin{array}{l}\text { FE } \\
(1) \\
\end{array}$ & $\begin{array}{c}\text { GMM } \\
\text { (2) }\end{array}$ & $\begin{array}{c}\text { GMM } \\
\text { (3) }\end{array}$ & $\begin{array}{c}\text { GMM } \\
(4) \\
\end{array}$ \\
\hline Log of Trade/GDPj & $\begin{array}{c}-0.091^{* * *} \\
(-8.33)\end{array}$ & & & $\begin{array}{l}-0.143^{*} \\
(-3.62)\end{array}$ \\
\hline Log of export/GDPj & & $\begin{array}{c}-0.135^{* * *} \\
(-6.97)\end{array}$ & $\begin{array}{c}-0.547^{* * *} \\
(-44.34)\end{array}$ & \\
\hline Log of imports/GDPj & & $\begin{array}{c}-0.235^{* * *} \\
(-8.72)\end{array}$ & $\begin{array}{c}-0.115^{* * *} \\
(-3.62)\end{array}$ & \\
\hline Capital Account & $\begin{array}{c}0.029^{* *} \\
(3.59)\end{array}$ & $\begin{array}{l}0.036^{*} \\
(3.50)\end{array}$ & $\begin{array}{c}0.027^{* * *} \\
(5.97)\end{array}$ & $\begin{array}{l}0.042^{*} \\
(3.35)\end{array}$ \\
\hline Log-Corruption rank index & $\begin{array}{l}0.001 \\
(0.08)\end{array}$ & $\begin{array}{l}0.002 \\
(0.18)\end{array}$ & $\begin{array}{l}0.002 \\
(0.62)\end{array}$ & $\begin{array}{l}-0.029 \\
(-1.52)\end{array}$ \\
\hline Log-natural Resource Availability & $-0.022^{* * *}$ & $-0.015^{* * *}$ & -0.013 & $-0.021^{* * * *}$ \\
\hline Exchange Volatility & $(-4.65)$ & $(-5.61)$ & $(-1.33)$ & $(-12.40)$ \\
\hline Bilateral Investment Treaties & $\begin{array}{l}0.117^{* *} \\
(4.43)\end{array}$ & $\begin{array}{l}0.135^{* *} \\
(3.95)\end{array}$ & $\begin{array}{l}0.026 \\
(1.10)\end{array}$ & $\begin{array}{l}0.149 \\
(2.28)\end{array}$ \\
\hline Cross Border Dummy & $\begin{array}{l}0.008 \\
(0.12)\end{array}$ & $\begin{array}{l}0.005 \\
(0.07)\end{array}$ & & $\begin{array}{l}-0.041 \\
(-0.54)\end{array}$ \\
\hline Labour Availability & $\begin{array}{l}0.018^{*} \\
(3.19)\end{array}$ & $\begin{array}{l}0.021^{* *} \\
(3.56)\end{array}$ & $\begin{array}{l}0.007^{* *} \\
(2.84)\end{array}$ & $\begin{array}{l}0.018^{* *} \\
(3.98)\end{array}$ \\
\hline Lag of Log FDI_flow/GDPj & & & $\begin{array}{l}0.434^{*} \\
(2.16)\end{array}$ & \\
\hline $\log$ of $\mathrm{FDI}_{\mathrm{OECD}} / \mathrm{GDPj}$ & & & & $\begin{array}{c}0.357^{* *} \\
(5.70)\end{array}$ \\
\hline Constant & $\begin{array}{l}-0.953^{*} \\
(-2.86)\end{array}$ & $\begin{array}{l}-1.119^{*} \\
(-3.08)\end{array}$ & $\begin{array}{l}-0.315^{*} \\
(-2.31)\end{array}$ & $\begin{array}{l}-0.851^{*} \\
(-2.77)\end{array}$ \\
\hline$N$ & 76 & 76 & 76 & 76 \\
\hline Fixed effect & Yes & Yes & Yes & Yes \\
\hline Sargan test & & 0.004 & 0.765 & 0.042 \\
\hline
\end{tabular}

Since trade is found not to positively influence South Africa outward FDI flows, then other factors do matter that member states need to pay attention to in order to attract intra-regional FDI. These factors are discussed below and we focus at model (2). The estimated results further indicate a positive and significant relationship between capital account openness (KA) and FDI and results are comparable to most empirical findings. This is not surprising as most of the SADC member states are committed to fully open their capital accounts. As such, there is need for SADC countries to continue pursuing policies that will ensure full capital account liberalization and not restrict capital inflows into some sectors. The variable capturing natural resource endowment (LNRA) is significant with unexpected negative sign. Whilst the results are in line with the view postulated by Sachs \& Warner (1995), as earlier stated, we cannot conclusively affirm this view as the results could be could be due to the nature of the proxy used. The dummy variable for bilateral investment treaties (BIT) is found to be positive and significantly related with FDI. The results are, however, in contrast to the empirical findings of Hallward-Driemeier (2003) and UNCTAD (1998), as they find bilateral investments not to matter in attracting FDI inflows. The results are therefore suggestive that SADC member states should encourage enforcement of the BITs so as to increase investor confidence and hence promote more intra-FDI flows. The labour supply variable (LPOP) is found to be positive and significant and the results are similar to Lederman (2010). In this regard, 
SADC efforts towards free labour migration in the region should continue to be supported by member states. The variable for inflation volatility (IV), phone density (LTEL) and rule of law (ROL) were highly correlated with other variables and since they were insignificant, they were dropped from the model. However, exchange rate volatility (EV) and common border dummy (CB) and Corruption index (CP) are found to be insignificant.

The study tests as to whether agglomeration effects do matter by including the lagged dependent variable and results from models (3) reveal a positive and significant coefficient for the lagged dependent variable. The results are similar to Campos and Kinoshita (2003) who found that agglomeration economies are one of the most important determinants of FDI. Results suggests that new South African investors are attracted in localities where there is presence of their home counterparts. This is contrary to common expectations since both countries belong to the same region, one would expect that these investors would easily gather information that would assist them in making a decision to locate their investments without necessarily relying on the existence of their counterparts. This partly confirms the argument that country-specific knowledge tends to be passed from firm to firm, and some firms often pursue a follow-my-leader strategy (Meyer and Skak, 2002).

The study further test as to whether FDI from developed countries complement or substitute FDI from South Africa. Results in model (4), show that the variable FDI_OECD is found to be positive and significant. In this regard, FDI flow from developed countries do complement FDI from South Africa in SADC countries. This could be that FDI from OECD bring in the much needed infrastructure and technology know-how in SADC countries which could attract FDI from South Africa. In this regard, SADC countries should make an effort to diversify its sources of FDI and encourage FDI from other regions, particularly OECD.

\section{Conclusion}

The objective of the study was to empirically investigate intra-SADC FDI, focusing on South Africa outward FDI, for the period of 1999 to 2010 . An augmented gravity model is estimated, employing both LSDV and GMM estimation techniques so as to obtain robust results. We find strong evidence that intra-trade and intra-FDI are substitutes within the SADC region. This is contrary to expectations, as the creation of SADC was intended to promote trade within the region which was expected to have a complementary effect on investment. This, therefore, implies that trade policies alone would not positively influence FDI, and hence SADC member countries ought to pursue explicit FDI policies to attract intra-FDI.

Openness to capital is found to be an important pull factor of FDI from South Africa, underscoring the need for SADC countries to continue pursuing national policies that will ensure consistent relaxation of exchange controls and removal of capital controls in all sectors. Results further show that bilateral investment treaties are key to promoting FDI from South Africa. As such, SADC member states should be encouraged to sign and enforce BITs which should, however, be designed in accordance with the SADC BIT model. Evidence is further found that availability of labour force is also an important pull factor in attracting investment from South Africa. In this regard, SADC efforts towards free labour migration in the region should continue to be supported by member states. Availability of natural resource is found to be negatively related with South African FDI, contrary to expectations. The results should be treated with caution as this could be due to the proxy used.

The study further finds strong evidence that agglomeration effects are important for South investors into SADC, despite that they are operating in a known region. This further underscores the need for SADC members to ensure that they pursue policies that would improve the investment environment not only to attract FDI but also to retain it which would in turn attract new investment. The study also investigated as to whether FDI from developed countries vis-à-vis that from SADC countries compete or complement each other. The estimated results indicate that FDI from developed countries complements with FDI from South Africa. From these findings, therefore, SADC countries which largely host South African investments should consider diversifying their sources of foreign direct investment.

There is need for a further detailed examination of the relationship between FDI and trade, particularly with respect to sectors. Future work should therefore consider this.

\section{Acknowledgments}

I would like to thank the African Economic Research Consortium (AERC) for providing financial support for this study and the paper was presented as December 2013. I acknowledge Dr Exley Silumbu and Proffessor Chinyamata Chipeta and Camelia Minoiu for their comments. I, however, remain solely responsible for the views and any shortcomings of the paper.

\section{References}

AFDB. (2013). Intra-SADC cross-border investments. NEPAD Regional integration brief September 2013.Tunis: 
AFDB.

Asiedu, E. (2006). Foreign direct investment in Africa: The role of natural resources, market size, government policy, institutions and political stability. World Economy, 29(1), 63-77. http://dx.doi.org/10.1111/j.1467-9701.2006.00758.x

Bezuidenhout, H., \& Naudé, W. (2008). Foreign direct investment and trade in the Southern African Development Community. UNU-WIDER, Research paper, 88. Helsinki: UNU-WIDER.

Blomstrom, M., \& Kokko, A. (1997). Regional integration and foreign direct investment. NBER Working Paper, 6019. Cambridge: NBER.

Brainard, S. L., \& Riker, D. A. (1997). Are multinationals exporting US jobs? NBER Working Paper, 5958. Cambridge: NBER.

Chinn, M. D., \& Ito, H. (2006). What matters for financial development? Capital controls, institutions, and $\begin{array}{lllll}\text { interactions. Journal of Development } & \text { Economics, } & 81(1), & 163-192 .\end{array}$ http://dx.doi.org/10.1016/j.jdeveco.2005.05.010

Chipeta, C. (2010). Regional Integration and Poverty Study. Johannesburg: Southern Africa Trust.

Dunning, J. H. (1980). Towards an eclectic theory of international production: Some empirical tests. Journal of International Business Studies, 11. http://dx.doi.org/10.1057/palgrave.jibs.8490593

Dunning, J. H. (1993). Multinational enterprises and the global economy. Wokingham: Addison-Wesley Publishers Ltd. Economic Review, 80(2), 92-96.

Gujarati, D. (2003). Basic Econometrics (p. 534). New York: Mcgraw Hill.

Hallward-Driemeier, M. (2003). Do bilateral investment treaties attract FDI? Only a bit and they could bite. World Bank Policy Research Working Paper Series, 3121. Washington: World Bank.

Hymer, S. (1976). The International Operations of Nation Firms: A study of foreign direct investment. Cambridge: MLT Press.

IMF. (2006). Balance of Payments Manual (6th ed.).Washington DC: IMF.

IMF. (2006). Methodology for CGER Exchange rate assessments. Washington DC: IMF.

Lall, S. (1983). Multinationals from India. In Lall (Ed.), The New Multinationals: The Spread of Third World Enterprises (pp. 21-87). New York: John Wiley \& Sons.

Lederman, D., Mengistae, T., \& Xu, C. L. (2010). Microeconomic consequences and macroeconomic causes of foreign direct investment in South African Economy. World Bank, Working Paper Series, 5415.

Loungani, P., \& Razin, A. (2001). How beneficial is foreign direct investment for developing countries? Finance \& Development, 38(2), 6-9. Washington: World Bank.

Lucas, R. (1990). Why doesn't capital flow from rich to poor countries? American

Markusen, J. R. (1984). Multinationals, multi-plant economics, and the gains from trade. Journal of International Economics, 16, 205-226. http://dx.doi.org/10.1016/S0022-1996(84)80001-X

Mhlanga, N., Blalock, G., \& Christy, R. (2009, 16-22 August). Understanding foreign direct investment in the Southern African Development Community: An analysis based on project-level data. Contributed Paper prepared for presentation at the International Association of Agricultural Economists Conference, Beijing, China. http://dx.doi.org/10.1111/j.1574-0862.2010.00440.x

Mitze, T., Alecke, B., \& Untiedt, G. (2007). Determining trade-FDI linkages for Germany: Evidence from a simultaneous equation approach using panel gravity models. MPRA Paper, 12245. Munich: MPRA.

Mundell, R. (1957). International trade and factor mobility. American Economic Review, 47(3), 321-335.

National Statistical Office. (2001). Malawi foreign Capital and Investor perception Survey Report 2001. Zomba: Government of Malawi.

National Statistical Office. (2005). Malawi foreign Capital and Investor perception Survey Reports 2005. Zomba: Government of Malawi.

National Statistical Office. (2009). Malawi foreign Capital and Investor perception Survey Reports. Zomba: Government of Malawi.

National Statistical Office. (2012). Malawi foreign Capital and Investor perception Survey Reports. Zomba: 
Government of Malawi.

Page, S. (1998). South-North Investment by developing countries in the EC: A sign of the emergence of new investors. In B. G. Hickman, \& L. Klein (Eds.), Link 1991-1992 Proceedings. World Scientific. http://dx.doi.org/10.1142/9789812816870_0011

Page, S., \& Willem te Velde, D. (2004). Foreign direct investment by African countries Overseas Development Institute. Paper for InWent / UNCTAD meeting on FDI in Africa, 22-24 November 2004. Addis Ababa: UNECA.

Penrose, E. T. (1987). Multinational corporations. The New Palgrave: A Dictionary of Economics, 562-4. London: Macmillan. http://dx.doi: 10.1007/s11575-007-0008-2

Rahman, Z. (2011). An empirical study on the relationship between foreign investment and international trade in Bangladesh. International Journal of Financial Research, 2(2). http://dx.doi.org/10.5430/ijfr.v2n2p33

Sachs, J. D., \& Warner, A. (1995). Economic reform and the process of global integration. Brookings Papers on Economic Activity, 1995(1), 1-118. http://dx.doi.org/10.2307/2534573

SADC Protocol on Finance and Investment. (2006). Retrieved from http://www.sadc.int/documents.publications/show/Protocol_on_Finance_Investment2006.pdf

SADC trade protocol. (1996). Retrieved from http://www.sadc.int/files /4613/5292/8370/Protocol_on_Trade1996.pdf

South African Reserve Bank. Full Quarterly Bulletin. (issues 1998 through 2012). Retrieved from https://www.resbank.co.za/Publications/Pages/Publications-Home.aspx

UNCTAD. (1998). Bilateral investment treaties in the Mid-1990s. World Investment Report, 1998. Geneva: United Nations. Retrieved from http://unctad.org/en/Docs/wir1998_en.pdf

UNCTAD. (2011a). Economic Development in Africa, Debt Sustainability: Oasis or Mirage? Geneva: UNCTAD. Retrieved from http://www.unctad.org/en/docs/gdsafrica20041_en.pdf

UNCTAD. (2011b). Non-Equity Modes of International Production and Development. World Investment Report, 2011. Retrieved from http://www.unctad-docs.org/files/UNCTAD-WIR2011

UNCTAD. (2012). Towards a New Generation of Investment Policies. World Investment Report 2012. Retrieved from http://www.unctad-docs.org/files/UNCTAD-WIR2012

Vernon, R. (1966). International investment and international trade in the product cycle. Quarterly Journal of Economics, 80, 190-207.http://dx.doi.org/10.2307/1880689

World Bank. (2010). Malawi Trade Brief. World Trade Indicators 2009/10: Country Trade Briefs. Washington, DC: World Bank. Retrieved from http://www.worldbank.org/wti

\section{Note}

Note 1. This is measured as a simple weighted average of kilometers of road, paved road, rail and telephone main line per population.

\begin{tabular}{|c|c|c|c|c|c|c|}
\hline \multicolumn{7}{|l|}{$\begin{array}{l}\text { Appendix A } \\
\text { Summary Statistics }\end{array}$} \\
\hline & LFDI_Flow/GDP & 94 & 0.112 & 0.2419 & 0.0003 & 1.159 \\
\hline & LTRD/GDP & 168 & 0.142 & 0.2035 & 0.007 & 0.959 \\
\hline & KA & 168 & -0.283 & 1.432 & -1.855 & 2.456 \\
\hline & LROL & 168 & 3.350 & 1.0967 & 0.541 & 4.422 \\
\hline & EV & 168 & 6.931 & 5.162 & 0 & 3.883 \\
\hline & IV & 168 & 105.17 & 1089.44 & 0.051 & 13695.7 \\
\hline & LDIST & 168 & 6.612 & 0.877 & 5.157 & 7.758 \\
\hline & LCPR & 168 & 1.484 & 0.2658 & 0.993 & 2.001 \\
\hline & LNRA & 156 & 11.637 & 23.839 & 0 & 177.3 \\
\hline & LGDP_j & 168 & 9.386 & 1.273 & 7.350 & 12.999 \\
\hline & IGDP_i & 168 & 12.645 & 0.243 & 12.270 & 12.999 \\
\hline & LTEL & 167 & 2.643 & 1.312 & 0.044 & 4.927 \\
\hline & BIT & 156 & 0.231 & 0.427 & 0 & 1 \\
\hline & CB & 156 & 0.385 & 0.488 & 0 & 1 \\
\hline
\end{tabular}




\section{Appendix B}

\section{Panel Causality Tests}

Ho: Coefficients of lags are jointly equal to zero

Ha: Coefficients of lags are jointly not equal to zero

\begin{tabular}{llll} 
South Africa & & & Prob (t) \\
\hline Variable Name & Variable Name & Chi-squared Lag=3 & \\
LTRD & LTEL & 0.99 & \\
EV & LTRD & 0.84 & \\
IV & EV & 0.96 & \\
LCP & IV & 0.86 & \\
KA & LCP & 0.80 & \\
LROL & KA & 0.93 & 0.11 \\
LNRA & LROL & 0.0004 & 0.001 \\
BIT & RA & 0.18 & \\
DIST & BIT & & \\
\hline
\end{tabular}

\section{Appendix C}

\section{Correlation Coefficients}

\begin{tabular}{|c|c|c|c|c|c|c|c|}
\hline & LFDI_STOCK & LTRD & KA & LROL & EV & IV & LDIST_A \\
\hline LFDI_STOCK & 1.0000 & & & & & & \\
\hline LTRD & 0.2163 & 1.0000 & & & & & \\
\hline KA & 0.5506 & 0.0041 & 1.0000 & & & & \\
\hline LROL & 0.2490 & -0.0550 & 0.2875 & 1.0000 & & & \\
\hline $\mathrm{EV}$ & 0.0114 & 0.4306 & -0.0988 & -0.0136 & 1.0000 & & \\
\hline IV & 0.0618 & 0.4379 & -0.0280 & 0.0391 & 0.9636 & 1.0000 & \\
\hline LDIST_A & 0.5035 & 0.0311 & 0.5636 & 0.3206 & 0.0285 & -0.0183 & 1.0000 \\
\hline LCPR & 0.1957 & -0.0245 & 0.0992 & 0.9643 & 0.0169 & 0.0547 & 0.1929 \\
\hline LNRA & -0.1780 & 0.3324 & -0.5165 & -0.1294 & 0.3282 & 0.3479 & -0.4255 \\
\hline LGDP_j & -0.4416 & -0.6070 & -0.3032 & -0.0289 & -0.2129 & -0.1917 & -0.7357 \\
\hline LTEL & -0.1669 & -0.1923 & -0.0002 & -0.2144 & -0.0560 & -0.0220 & -0.5363 \\
\hline BIT & -0.2991 & -0.3103 & -0.4422 & -0.2906 & -0.1422 & -0.0756 & -0.8980 \\
\hline LFDI_OECD & 0.3411 & 0.8012 & -0.0034 & 0.0716 & 0.0935 & 0.1246 & 0.0389 \\
\hline \multirow[t]{2}{*}{$\mathrm{CB}$} & -0.4311 & -0.3051 & 0.0137 & -0.3580 & -0.1994 & -0.1060 & -0.7281 \\
\hline & LCPR & LNRA & LGDP_j $_{\lrcorner}$ & LTEL & BIT & LFDI_OECD & $\mathrm{CB}$ \\
\hline LCPR & 1.0000 & & & & & & \\
\hline LNRA & -0.0192 & 1.0000 & & & & & \\
\hline LGDP_j & 0.0370 & 0.0975 & 1.0000 & & & & \\
\hline LTEL & -0.2007 & 0.0583 & 0.6606 & 1.0000 & & & \\
\hline BIT & -0.1803 & 0.3421 & 0.8297 & 0.5078 & 1.0000 & & \\
\hline LFDI_OECD & 0.1131 & 0.2925 & -0.4931 & -0.1945 & -0.2293 & 1.0000 & \\
\hline CB & -0.3732 & -0.0186 & 0.7212 & 0.6725 & 0.7136 & -0.3029 & 1.0000 \\
\hline
\end{tabular}

\section{Appendix D}

\section{Pooled, Fixed vs Random Effects Tests}

\begin{tabular}{ll}
\hline Panel Test & Results \\
\hline Pooled vs Fixed Effects & $\mathrm{F}(8,54)=4.21$ or Prob $>\mathrm{F} 0.0006$ \\
Pooled vs Random Effects & Wald $\operatorname{chi}^{2}(9)=135.06 \quad$ or Prob $>\mathrm{chi}^{2}=0.000$ \\
Fixed Effect vs Random Effects & Hausman test: data fails to meet the asymptotic assumptions of the Hausman test \\
Joint Significance of Time effects & $\mathrm{F}(11,82)=0.28 \quad$ Prob $>\mathrm{F}=0.9888$ \\
Joint significance of Cross section effects & $\mathrm{F}(9,84)=2.91 \quad$ Prob $>\mathrm{F}=0.0000$ \\
\hline
\end{tabular}




\section{Appendix E}

South Africa- Dependent variable Trade

\begin{tabular}{|c|c|c|c|c|c|c|c|c|}
\hline & LSDV & LSDV & LSDV & GMM & GMM & GMM & LSDV & GMM \\
\hline Model & 1 & 2 & 3 & 4 & 5 & 6 & 7 & 8 \\
\hline \multirow[t]{2}{*}{ Lfdi_stock/GDP ${ }_{\mathrm{j}}$} & $-0.160^{* * *}$ & $-0.160^{* *}$ & $-0.212^{* *}$ & $-0.212^{* *}$ & -0.436 & -0.436 & $-0.305^{* *}$ & $-0.338^{*}$ \\
\hline & $(0.064)$ & $(0.064)$ & $(0.061)$ & $(0.061)$ & $(0.371)$ & $(0.371)$ & $(0.124)$ & $(0.165)$ \\
\hline Account & $0.013^{* * *}$ & $0.013^{* * *}$ & $0.026^{* *}$ & $0.026^{* *}$ & $0.047^{*}$ & $0.047^{*}$ & $0.021^{*}$ & $0.044^{*}$ \\
\hline Openness & $(0.002)$ & $(0.002)$ & $(0.008)$ & $(0.008)$ & $(0.024)$ & $(0.024)$ & $(0.009)$ & $(0.021)$ \\
\hline Log-corruption $\quad$ rank & -0.002 & -0.002 & -0.006 & -0.006 & 0.003 & 0.003 & -0.013 & -0.009 \\
\hline index & $(0.012)$ & $(0.012)$ & $(0.012)$ & $(0.012)$ & $(0.023)$ & $(0.023)$ & $(0.031)$ & $(0.039)$ \\
\hline Log-natural resource & 0.002 & 0.002 & 0.001 & 0.001 & 0.008 & 0.008 & -0.003 & 0.003 \\
\hline intensity & $(0.004)$ & $(0.004)$ & $(0.003)$ & $(0.003)$ & $(0.022)$ & $(0.022)$ & $(0.002)$ & $(0.003)$ \\
\hline Exchange & $0.000^{* * * *}$ & $0.000^{* * *}$ & & & & & $0.000^{* * *}$ & \\
\hline volatility & $(0.000)$ & $(0.000)$ & & & & & $(0.000)$ & \\
\hline Bilateral investment & 0.040 & 0.040 & -0.025 & -0.025 & $-0.310^{* * * *}$ & $-0.310^{* * * *}$ & -0.031 & 0.138 \\
\hline treaties & $(0.030)$ & $(0.030)$ & $(0.029)$ & $(0.029)$ & $(0.048)$ & $(0.048)$ & $(0.036)$ & $(0.113)$ \\
\hline \multirow[t]{2}{*}{ Common border } & $-0.082^{* * *}$ & $-0.082^{* * *}$ & $-0.111^{* *}$ & $-0.111^{* *}$ & & & & $-0.147^{*}$ \\
\hline & $(0.021)$ & $(0.021)$ & $(0.034)$ & $(0.034)$ & & & & $(0.061)$ \\
\hline \multirow[t]{2}{*}{ Labour availability } & $0.006^{* *}$ & $0.006^{* *}$ & $0.009^{* * *}$ & $0.009^{* * *}$ & $-0.011^{*}$ & $-0.011^{*}$ & $0.008^{* * *}$ & $0.012^{* * *}$ \\
\hline & $(0.002)$ & $(0.002)$ & $(0.001)$ & $(0.001)$ & $(0.006)$ & $(0.006)$ & $(0.001)$ & $(0.003)$ \\
\hline \multirow[t]{2}{*}{ Lag of lfdi_stock/GDP } & & & & & 0.953 & 0.953 & & \\
\hline & & & & & $(0.664)$ & $(0.664)$ & & \\
\hline \multirow[t]{2}{*}{ Lfdi_oecd/GDP ${ }_{\mathrm{j}}$} & & & & & & & $0.581^{* * *}$ & $0.492^{* *}$ \\
\hline & & & & & & & $(0.042)$ & $(0.158)$ \\
\hline \multirow[t]{2}{*}{ Constant } & -0.121 & -0.121 & $-0.242^{* *}$ & $-0.242^{* *}$ & $0.888^{* *}$ & $0.888^{* *}$ & $-0.253^{*}$ & -0.382 \\
\hline & $(0.125)$ & $(0.125)$ & $(0.070)$ & $(0.070)$ & $(0.312)$ & $(0.312)$ & $(0.113)$ & $(0.277)$ \\
\hline Observations & 76 & 76 & 76 & 76 & 61 & 61 & 58 & 58 \\
\hline Fixed effects & Yes & Yes & yes & yes & yes & yes & Yes & Yes \\
\hline
\end{tabular}

Standard errors in parentheses ${ }^{*} p<0.10,{ }^{* *} p<0.05,{ }^{* * *} p<0.01$.

\section{Copyrights}

Copyright for this article is retained by the author(s), with first publication rights granted to the journal.

This is an open-access article distributed under the terms and conditions of the Creative Commons Attribution license (http://creativecommons.org/licenses/by/3.0/). 